\title{
Politik Hukum Pemerintahan Islam Pasca Nabi Muhammad Saw
}

\author{
(Studi Kepemimpinan Umar Bin Khattab)* \\ (THE LEADERSHIP TRANSITION AFTER PROPHET MUHAMMAD) \\ Hidayatulloh \\ Sekolah Tinggi Agama Islam al Karimiyah \\ Jl. Ir. H. Juanda No. 95, Ciputat, Jakarta \\ E-mail: dayatfsh@yahoo.co.id
}

\begin{abstract}
The leadership transition after Prophet Muhammad seems to be attractive which is seen from political legal administration. This article examines the period of Umar bin Khattab's leadership as the second caliph of Islamic history. Many legacies of national policy in his period which had changed the political aspects of Islamic administration and had been the main resources for heads of state up to now. Responsive legal politics became one of the superiorities of others. Using normative legal research, this article used second sources taken from many scientific sources. Afterwards the author explains many sources with historical approach to get systematic knowledge.
\end{abstract}

Keywords: Legal Politics, Umar bin Khattab, Political Transition

\begin{abstract}
Abstrak: Transisi kepemimpinan pasca Nabi Muhammad SAW memiliki daya tarik dari sisi politik hukum pemerintahan. Tulisan ini mengkaji masa kepemimpinan Umar bin Khattab sebagai khalifah kedua dalam sejarah Islam. Banyak warisan kebijakan negara di masanya yang telah mengubah aspek-aspek politik hukum pemerintahan Islam dan telah menjadi referensi utama bagi pemimpin negara hingga saat ini. Politik hukum responsif menjadi salah satu keunggulan dari banyak keunggulan lainnya. Dengan metode penelitian hukum normatif, tulisan ini menggunakan data sekunder yang diambil dari beberapa literatur ilmiah. Kemudian penulis menguraikan bebagai sumber data dengan pendekatan sejarah untuk menghasilkan kajian yang sistematis.
\end{abstract}

Keywords: politik hukum, Umar bin Khattab, transisi politik

${ }^{*}$ Diterima tanggal naskah diterima: 12 April 2015, direvisi: 22 April 2015, disetujui untuk terbit: 25 Juni 2015. 


\section{Pendahuluan}

Islam adalah al-din. Dalam bahasa Inggris disebut the religion. ${ }^{1}$ Istilah tersebut hanya terdapat dalam sumber ajaran umat muslim yaitu Al-Quran. Ada dua ayat yang menyebutkan secara tegas bahwa Islam adalah al-din. Pertama, surat Ali Imran (3): 19 yang berbunyi:

$$
\text { إِنَّ الدِّيْنَ عِنْدَ اللَهِ الإنَاَْمُ. }
$$

Sesungguhnya agama yang diridhai di sisi Allah hanyalah Islam.

Dalam ayat lainnya tercantum dalam surat Al-Maidah (5): 3 sebagai berikut:

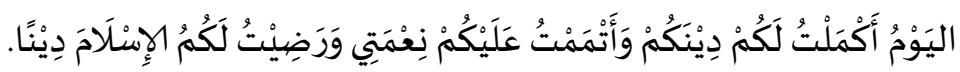

Pada hari ini Kusempurnakan untuk kamu agamanu dan telah Kucukupkan nikmatKu dan telah Kuridhai Islam sebagai agama bagimu. ${ }^{2}$

Perkataan al-din dalam bahasa Indonesia diterjemahkan dengan perkataan "agama". ${ }^{3}$ Sesungguhnya secara konsepsional perkataan al-din dan "agama" mengandung konotasi masing-masing. Perkataan agama yang sudah lazim digunakan dalam bahasa Indonesia berasal dari bahasa Sansekerta yang memiliki konotasi sangat erat dengan tradisi dalam agama Hindu dan Budha. Perkataan al-din sebagaimana tercantum dalam dua ayat Al-Quran tersebut di atas merupakan suatu konsep yang terdiri dari dua komponen pokok pengaturan hubungan antara manusia dengan Allah (hubungan vertikal) dan antara manusia dengan manusia dalam suatu masyarakat atau negara, bahkan

${ }^{1}$ Dalam kamus Oxford kata religion berarti belief in the existence of god or gods, especially the belief that they created the universe and gave human beings a spiritual nature which continues to exist after the death of the body. Oxford Advance Learner Dictionary. $5^{\text {th }}$ edition, (New York: Oxford University Press), hlm. 988.

2 Islam sebagai ajaran yang sempurna bagi seluruh manusia. Ayat pertama menjelaskan hal tersebut. Sedangkan ayat kedua menjelaskan kesempurnaan Islam. Muhammad Tahir Azhary, Negara Hukum: Suatu Studi Tentang Prinsip-prinsipnya Dilihat dari Segi Hukum Islam, Implementasinya pada Periode Madinah dan Masa Kini, Edisi Kedua. Cet-2. (Jakarta: Kencana Prenada Media, 2004), hlm. 20.

3 W.J.S. Poerwadarminta, Kamus Umum Bahasa Indonesia, bagian pertama, cet-4. (Jakarta: Balai Pustaka, 1966), hlm. 21. 
mungkin pula antar negara serta antar manusia dengan lingkungan hidupnya (hubungan horizontal). ${ }^{4}$

Jadi istilah al-din dalam Al-Quran mengandung konsep bidimensional yang mencakup dua aspek kehidupan manusia yaitu aspek religious-spiritual dan aspek kemasyarakatan yang bertumpu pada ajaran tauhid (unitas). Di sinilah letak sifat khas Islam sebagai al-din. Oleh karena itu dapat dibedakan, ketika kita menggunakan istilah agama, penggunaannya hanyalah sekedar untuk kemudahan berkomunikasi. Namun, bila digunakan istilah agama Islam, konotasi yang dimaksud adalah al-din al-islami atau konotasi al-din menurut konsep Al-Quran sebagaimana tersebut di atas. ${ }^{5}$

Berdasarkan konsep Islam sebagai al-din tersebut, maka dalam sejarah pertumbuhan awal Islam di kota Madinah terbentuklah sebuah pemerintahan pertama dalam Islam. ${ }^{6}$ Dalam hal ini Nabi Muhammad SAW bertindak sebagai pemimpin agama sekaligus pemimpin negara. Keberhasilan nabi menyatukan suku-suku Arab yang ada di jazirah Arab adalah sebuah keberhasilan sejarah pembentukan sebuah negara yang berprinsipkan negara teokrasi.

\section{Transisi Politik Pasca Nabi Muhammad Saw}

Nabi Muhammad SAW wafat pada usia 63 tahun di hari Senin, 11 Rabiul Awal tahun 11 Hijriyah atau bertepatan dengan 8 Juli tahun 632 Masehi. ${ }^{7}$ Nabi Muhammad SAW adalah pemimpin agama sekaligus pemerintahan. Perannya sebagai pemimpin agama merupakan representasi dari tugasnya sebagai wakil Tuhan di muka bumi. Melalui dirinya, Tuhan mengatur aspek kehidupan manusia serta prinsip-prinsip kebenaran dan keadilan dengan menurunkan firman-Nya berupa kitab suci Al-Quran.

${ }^{4}$ Muhammad Tahir Azhary, Negara Hukum: Suatu Studi Tentang Prinsip-prinsipnya Dilihat dari Segi Hukum Islam, Implementasinya pada Periode Madinah dan Masa Kini, hlm. 27.

${ }^{5}$ M. Rasidi, Koreksi Terhadap Dr. Harun Nasution tentang Islam Ditinjau dari Berbagai Aspeknya, (Jakarta: Bulan Bintang, 1977), hlm. 15.

${ }^{6}$ Imam Ghazali Said, Antara Piagam Madinah dan Konstitusi Indonesia: Antara Idealisasi Syariat Islam dan Lokalitas Sosio-Kultural Masyarakat Indonesia. Kumpulan tulisan dalam buku Formalisasi Syariat Islam di Indonesia: Sebuah Pergulatan Yang Tak Pernah Putus. Cet-5. (Jakarta: Renaisan, 2005), hlm. 109.

7 Umar Abd al-Jabbar, Khulashah Nur al-Yaqinfi Siyarati Sayyid al-Mursalin. Juz 2. Surabaya: Maktabah Muhammad bin Ahmad Nabhan wa Auladih, t.t., hlm. 89. Lihat pula A. Latif Osman, Ringkasan Sejarah Islam, Cet-30. (Jakarta: Widjaya, 2000), hlm. 39. 
Sedangkan perannya sebagai pemimpin pemerintahan merupakan tugas politik yang diembannya sejak membangun Negara Madinah yang berlandaskan prinsip-prinsip ajaran Islam. ${ }^{8}$ Pada masa itu, pemerintahan Islam sudah melakukan hubungan politik luar negeri dengan Kerajaan Najasy dan Persia. ${ }^{9}$

Negara Madinah yang dipimpin oleh Nabi Muhammad SAW berdasarkan Perjanjian al-Aqabah I dan II serta Konstitusi Madinah. Perjanjian al-Aqabah adalah sebuah perjanjian antara nabi dengan delegasi penduduk Madinah yang telah memilih nabi baik sebagai pemimpin politik maupun pemimpin agama. Perjanjian al-Aqabah I terjadi pada tahun $620 \mathrm{M}$, sedangkan Perjanjian al-Aqabah II terjadi pada tahun $621 \mathrm{M} .{ }^{10}$

Sedangkan yang dimaksud dengan Konstitusi Madinah adalah undang-undang dasar Negara Madinah yang terutama mengatur kewajibankewajiban dan hak-hak warga negaranya. Para pakar tentang Islam mengenal konstitusi ini sebagai konstitusi tertulis pertama di dunia. ${ }^{11}$

8 Salah satu karakteristik agama Islam pada awal penampilannya adalah kejayaan di bidang politik melalui serangkaian ekspedisi militer di bawah kepemimpinan Nabi Muhammad SAW. Kesuksesan spektakuler ini dilanjutkan oleh para sahabat pasca nabi wafat. Fakta historis tersebut mengisyaratkan bahwa Islam adalah terkait dengan persoalan kenegaraan. Sehingga tidak heran muncul jargon "Islam adalah agama dan negara". Lihat selengkapnya elaborasi Musdah Mulia yang dikutip oleh Imam Ghazali Said, Antara Piagam Madinah dan Konstitusi Indonesia: Antara Idealisasi Syariat Islam dan Lokalitas Sosio-Kultural Masyarakat Indonesia. Kumpulan tulisan dalam buku Formalisasi Syariat Islam di Indonesia: Sebuah Pergulatan Yang Tak Pernah Putus. Cet-5. (Jakarta: Renaisan, 2005), hlm. 123.

9 Salah satu bukti politik negeri pemerintahan Islam adalah surat Nabi Muhammad SAW yang dikirimkan kepada Raja Najasy dan Kisra, Raja Persia. Syaikh Syaifurrahman AlMubarakfuri, Sirah Nabawiyah. Penerjemah: Kathur Suhardi. Cet-1. (Jakarta: Pustaka Al-Kautsar, 1997), hlm. 405.

10 Perjanjian al-Aqabah I berisi kesepakatan antara nabi dan wakil kaum madinah (dahulu bernama Yatsrib) berjumlah 12 orang terdiri dari suku Aus dan suku Khazraj. Mereka berbaiat kepada nabi untuk tidak menyekutukan Allah dengan sesuatu apapun, tidak mencuri, tidak berzina, tidak membunuh anak-anak mereka, tidak berdusta, dan tidak mengingkari kebaikan. Sedangkan dalam Perjanjian al-Aqabah II, berbaiat kepada nabi 73 laki-laki dan 2 perempuan yang isi perjanjiannya adalah mereka tidak menyekutukan Allah dengan sesuatu apapun, dan akan membela nabi bila berhijrah dan membangun pemerintahan di Madinah. Umar Abd al-Jabbar, Khulashah Nur al-Yaqinfi Siyarati Sayyid al-Mursalin, Juz 1. (Surabaya: Maktabah Muhammad bin Ahmad Nabhan wa Auladih, t.t.), hlm. 47.

${ }_{11}$ Muhammad Tahir Azhary, Negara Hukum: Suatu Studi Tentang Prinsip-prinsipnya Dilihat dari Segi Hukum Islam, Implementasinya pada Periode Madinah dan Masa Kini. Edisi Kedua. Cet-2. (Jakarta: Kencana Prenada Media), 2004, hlm. 18 dan Imam Ghazali Said, Antara Piagam Madinah dan Konstitusi Indonesia: Antara Idealisasi Syariat Islam dan Lokalitas Sosio-Kultural 
Pasca wafatnya nabi tidak menunjuk sahabat yang menggantikan posisinya. ${ }^{12}$ Sehingga dalam sejarah tercatat bahwa muncul sedikit gesekan antara golongan Muhajirin dan golongan Anshar..$^{13}$ Mereka masing-masing berpendapat bahwa yang berhak menggantikan nabi sebagai pemimpin politik dan pemerintahan adalah dari golongan mereka. Golongan Anshar lebih dahulu hendak melakukan suksesi dengan berencana mengangkat Sa'd bin Ubadah. Mereka berkumpul di suatu tempat bernama Saqifah Bani Sa'idah. Rencana mereka diketahui oleh golongan Muhajirin yang dipimpin oleh Abu Bakar, Umar, dan Abu Ubaidah. Terjadi perselisihan pendapat di antara kedua golongan. Namun dengan ide cemerlang dari Umar bin Khattab, ia mengajak umat muslim untuk memilih Abu Bakar secara aklamasi dengan diplomasi yang menggunakan pendekatan lobi-lobi sehingga melunturkan hati golongan Anshar yang awalnya bersikukuh memilih pemimpin dari golongan mereka. ${ }^{14}$

\section{Demokrasi dan Suksesi Kepemimpinan}

Pengertian tentang demokrasi yang paling umum digunakan adalah "pemerintahan oleh masyarakat". ${ }^{15}$ Dalam hal ini masyarakat memilih wakilwakil mereka sebagai representasi keterwakilan mereka dalam pemerintahan.

Masyarakat Indonesia. Kumpulan tulisan dalam buku Formalisasi Syariat Islam di Indonesia: Sebuah Pergulatan Yang Tak Pernah Putus. Cet-5. (Jakarta: Renaisan, 2005), hlm. 123.

12 Dalam hal ini posisi yang tergantikan adalah sebagai pemimpin politik dan pemerintahan, bukan sebagai nabi dan rasul yang notabene dalam Islam adalah tertutup karena Nabi Muhammad SAW adalah penutup nabi dan rasul. Tidak ada lagi nabi dan rasul yang diutus oleh Allah ke muka bumi ini. Hal ini ditegaskan dalam Al-Quran surat Al-Ahzab: 40. Begitu pula dalam hadis riwayat Muslim. Abu al-Husain Muslim bin al-Hajjaj, Shahih Muslim. Juz 4, cet-1. (Beirut: Dar al-Hadis, 1997), hlm. 133. Kitab al-Fadhail, bab fi asma ihi, no hadis 2354.

13 Golongan Muhajirin adalah imigran muslim dari kota Mekah yang berhijrah bersama Nabi Muhammad SAW, sedangkan golongan Anshar adalah kaum pribumi yang memeluk agama Islam dan bersama-sama dengan golongan Muhajirin menjadi pembela nabi dan menjadikannya kepala pemerintahan.

${ }^{14}$ Abd al-Jabbar, Khulashah Nur al-Yaqinfi Siyarati Sayyid al-Mursalin, Juz 3. (Surabaya: Maktabah Muhammad bin Ahmad Nabhan wa Auladih, t.t.), hlm. 8.

${ }^{15}$ Model demokrasi identik dengan pemerintahan yang dikendalikan oleh masyarakat. Konsep demokrasi memiliki kemiripan dengan konsep syura dalam Islam, meskipun tidak sama persis. Imam Ghazali Said, Antara Piagam Madinah dan Konstitusi Indonesia: Antara Idealisasi Syariat Islam dan Lokalitas Sosio-Kultural Masyarakat Indonesia. Kumpulan tulisan dalam buku Formalisasi Syariat Islam di Indonesia: Sebuah Pergulatan Yang Tak Pernah Putus. Cet-5. (Jakarta: Renaisan, 2005), hlm. 109. 
Meskipun model-model demokrasi memiliki bentuk yang bervariasi, secara umum dikatakan demokrasi adalah sebuah pemerintahan yang diatur oleh wakil-wakil representasi dari masyarakat. ${ }^{16}$

Selanjutnya Robert A. Dahl menjelaskan, sebagaimana dikutip oleh Arend Lijphart, bahwasanya kehidupan demokrasi akan eksis jika pemerintahan yang berkuasa menjalankan delapan jaminan konstitusional sebagai berikut:

1. Freedom to form and join organizations;

2. Freedom of expression;

3. The right to vote;

4. Eligibility for public office;

5. The right of political leaders to compete for support and votes;

6. Alternative sources of information;

7. Free and fair elections;

8. Institutions for making government policies depend on votes and other expressions of preference. ${ }^{17}$

Demokrasi memiliki esensi sebagai bentuk organisasi politik. ${ }^{18}$ Masyarakat memiliki akses untuk berpartisipasi secara luas terhadap aktivitas sosial politik dalam negara. Setiap individu dapat berkompetisi dengan bebas dalam mengeluarkan aspirasi dan keinginan politiknya. Sehingga demokrasi menjadi sebuah kesatuan hasil atas konflik-konflik kepentingan dan keinginan dalam masyarakat. ${ }^{19}$

16 Arend Lijphart, Democracies: Patterns of Majoritarian and Consensus Government in Twenty-One Countries. Dalam Politik Hukum 1 yang dikumpulkan oleh Satya Arinanto, Program Pascasarjana Fakultas Hukum Universitas Indonesia. Edisi 1, 2001, hlm. 25.

17 Arend Lijphart, Democracies: Patterns of Majoritarian and Consensus Government in Twenty-One Countries. Dalam Politik Hukum 1 yang dikumpulkan oleh Satya Arinanto, Program Pascasarjana Fakultas Hukum Universitas Indonesia. Edisi 1, 2001, hlm. 26.

${ }^{18}$ Adam Przeworski, Democracy as a Contingent Outcome of Conflicts. Kumpulan tulisan dalam Constitutionalism and Democracy. Buku I Politik Hukum yang dikumpulkan oleh Satya Arinanto, Program Pascasarjana Fakultas Hukum Universitas Indonesia. Edisi 1, 2001, hlm. 237.

${ }^{19}$ Adam Przeworski, Democracy as a Contingent Outcome of Conflicts. Kumpulan tulisan dalam Constitutionalism and Democracy. Buku I Politik Hukum yang dikumpulkan oleh Satya Arinanto, Program Pascasarjana Fakultas Hukum Universitas Indonesia. Edisi 1, 2001, hlm. 233. 
Bila kita membicarakan hubungan demokrasi dengan Islam, hubungan yang kita bicarakan notabenenya bersifat aksiomatis. Islam merupakan agama dan risalah yang mengandung asas-asas yang mengatur ibadah, akhlak, dan muamalat di antara manusia. Berbeda dengan demokrasi yang hanya merupakan sistem pemerintahan dan mekanisme kerja antar anggota masyarakat serta simbol yang membawa banyak nilai-nilai positif. Fahmi Huwaydi berkesimpulan bahwa Islam telah dideskreditkan oleh dua hal, yaitu ketika Islam dibandingkan dengan demokrasi dan ketika dikatakan bahwa Islam bertentangan dengan demokrasi. Pertimbangannya adalah Islam memiliki peradaban yang spesifik, sementara demokrasi inkonsisten. ${ }^{20}$

Bila demokrasi mengatur sistem sukses dalam pemerintahan, berbeda dengan Islam. Al-Quran dan al-Sunnah, keduanya adalah sumber ajaran Islam yang otoritatif, tidak menjelaskan bagaimana cara memilih pemimpin. Bahkan disebutkan sebelumnya bahwa Nabi Muhammad SAW tidak menunjuk penggantinya sebagai pemimpin politik atau memberikan ketentuan-ketentuan yang mengatur tentang suksesi kepemimpinan dalam Islam. Model-model suksesi pemimpin muncul dari ijtihad para sahabat. ${ }^{21}$ Misalnya suksesi Abu Bakar menjadi khalifah pertama dengan metode musyawarah atau syura yang terpilih secara aklamasi oleh golongan Muhajirin dan golongan Anshar.

Berdasarkan pengalaman umat muslim dalam suksesi kepemimpinan, al-Mawardi merumuskan dua cara yang dilakukan dalam memilih pemimpin. Pertama, pemimpin dipilih oleh sebuah kelompok yang disebut Ahl al-'Aqdi wa al-Hilli, yaitu sebuah kumpulan orang-orang terkemuka yang memiliki hak dan kewenangan memilih pemimpin melalui musyawarah di antara mereka. ${ }^{22}$

20 Fahmi Huwaydi, Demokrasi, Oposisi, dan Masyarakat Madani, Penerjemah: Muhammad Ghaffar. (Bandung: Mizan, 1996), hlm. 151.

${ }^{21}$ Ijtihad adalah aktivitas melakukan istinbath/menarik garis hukum-hukum syara' dari dalil-dalilnya yang terperinci dalam syariat. Ijtihad dilakukan terhadap perkara-perkara yang tidak dijelaskan oleh Al-Quran dan Al-Sunnah atau sudah dijelaskan namun tidak secara eksplisit. Dalam hal ini model suksesi kepemimpinan adalah ijtihad terhadap perkara yang belum sama sekali diatur dalam syariat. Wahbah Zuhaili, Al-Wajiz fi Ushul al-Figh, (Beirut: Dar al-Fikr al-Mu'ashir, 1999), hlm. 231.

${ }^{22}$ Para cendikiawan muslim berbeda pendapat tentang jumlah anggota ahl al-'aqdi wa al-hilli. Sebagian berpendapat harus mayoritas masyarakat di setiap negeri dalam wilayah kekuasaan sebagaimana sewaktu pemilihan Abu Bakar sebagai khalifah pertama. Pendapat lainnya tidak harus mayoritas masyarakat. Cukup lima orang ahli sebagai wakil representatif dari masyarakat. Abu al-Husain Ali bin Muhammad al-Mawardi, Al-Ahkam al-Sulthaniyah wa alWilayat al-Diniyah, Cet-3. (Beirut: Dar al-Kotob al-Islamiyah, 2006), hlm. 7. 
Disyaratkan bagi anggota-anggota tim ini adalah bersifat adil, memiliki kapasitas ilmu dalam menentukan pemimpin, dan mampu berijtihad dan mendalami persoalan yang ditugaskan dalam pemilihan.

Kedua, suksesi kepemimpinan berada di tangan pemimpin sebelumnya. ${ }^{23}$ Sebelum pemimpin berkuasa meninggal dunia, ia berwasiat atau menunjuk langsung orang yang akan menggantikannya. Hal ini sering terjadi dalam sebuah pemerintahan yang berdasarkan dinasti atau kerajaan.

\section{Suksesi Umar Bin Khattab}

Abu Bakar menjadi khalifah selama dua tahun, yakni tahun 11-13 H/632-634 M.24 Sebelum wafatnya, ia bermusyawarah dengan para sahabat penting dalam pemerintahannya tentang keinginannya menunjuk Umar bin Khattab sebagai penggantinya. Semua sahabat terkemuka yang dipanggilnya setuju dengan penunjukkan Umar, meskipun mereka memberikan sedikit catatan akan perilaku Umar yang terlalu keras dan dikhawatirkan memecah persatuan Islam..$^{25}$

Keinginan Abu Bakar menjadikan Umar sebagai pengantinya adalah sebuah keputusan yang bebas dari intervensi dan kepentingan politik pribadi. Abu Bakar tidak memiliki hubungan kerabat dengan Umar apalagi hubungan bisnis. Apa yang dilakukannya adalah merupakan sebuah pilihan berdasarkan kualitas dan kapabilitas Umar sebagai pemimpin umat. Apalagi tidak dinafikan dalam sejarah bahwa Umar memiliki peran penting dalam membangun kekuatan Islam dan peradabannya yang luar biasa berkembang

${ }^{23}$ Abu al-Husain Ali bin Muhammad al-Mawardi, Al-Ahkam al-Sulthaniyah wa alWilayat al-Diniyah, Cet-3. (Beirut: Dar al-Kotob al-Islamiyah, 2006), hlm. 7.

${ }^{24}$ Muhammad Husain Haekal, Umar bin Khattab: Sebuah Telaah Mendalam Tentang Pertumbuhan Islam dan Kedaulatannya Masa Itu, Penerjemah: Ali Audah. Cet-10. (Jakarta: Litera Antar Nusa, 2009), hlm. 9.

${ }^{25}$ Perdebatan tentang penunjukkan Umar sebagai pengganti Abu Bakar berlangsung cukup alot. Namun keteguhan hati Abu Bakar akan pendiriannya sunguh kuat hingga meyakinkan para sahabat terkemuka di pemerintahannya. Akhirnya mereka yakin umat muslim akan patuh dan tunduk kepada Umar. Berikut kutipan perkataan Abu Bakar kepada para sahabat:"If I met Allah my God and He asked me about it, I said I made the best of your people as my successor. And he said: Do you accept whom I make my successor, I swear by Allah, I spared no effort or preferred a relative. I made Omar Ibn al-Khattab my successor. You have to listen him and obey him. They said: We heard and obeyed." Mohammad Redha, Al-Farouk Omar Ibn al- Khattab The Second Caliph, Cet-1. (Beirut: Dar al-Kotob al-Islamiyah, 1999), hlm. 7. 
di masa itu. Umar tidak hanya cakap sebagai pemimpin, tetapi ia juga memiliki kesalehan individu dan sosial serta jiwa kesederhanaannya yang membuatnya tidak terbuai oleh kekuasaan. ${ }^{26}$

\section{Kepribadian Umar}

Umar adalah putra dari Khattab, seorang pemimpin kaum Adi di Mekah. Dilahirkan di Mekah pada 13 tahun pasca 'Amm al-Fiil.. ${ }^{27}$ Memiliki tubuh tinggi, besar, dan kekar. Kulitnya putih kemerahan. Ia memiliki sifat yang keras, pemberani, dan cerdas. Dia dikenal pandai bergulat dan berkuda. Kemahiran tersebut yang membuatnya beberapa kali dipilih menjadi komandan dalam pertempuran di medan perang. Pada awalnya ia sangat memusuhi Islam dan menyiksa orang-orang Mekah yang memeluk agama tersebut. Namun hal itu berubah seratus delapan puluh derajat ketika ia memeluk agama Islam pada usianya menginjak 26 tahun. Ia menjadi pembela Islam dan pemeluknya yang sangat berani dan menjadi sahabat Nabi Muhammad SAW yang selalu berada di sampingya. ${ }^{28}$

Umar memiliki kepercayaan diri yang luar biasa dalam hidupnya. Ia senang belajar dan memburu pengetahuan sehingga menjadikannya sebagai pemikir akan nasib masyarakatnya. Ia sangat berpegang teguh atas pendiriannya dan tidak mau mengalah dalam perdebatan. Karena sikap keras dan ketegarannya itu sehingga dengan fanatiknya ia bertindak sewenangwenang. Ia mempertahankan sikapnya dengan tangan besi dan ketajaman lidahnya. ${ }^{29}$

${ }^{26}$ Muhammad Husain Haekal, Umar bin Khattab: Sebuah Telaah Mendalam Tentang Pertumbuhan Islam dan Kedaulatannya Masa Itu, hlm. 16.

27 'Amm al-Fiil adalah Tahun Gajah yang dimulai perhitungannya ketika Raja Abraham dari Abbesinia menyerang Ka'bah yang menjadi pusat ibadah kaum Arab. A. Latif Osman, Ringkasan Sejarah Islam, Cet-30. (Jakarta: Widjaya, 2000), hlm. 12.

${ }^{28}$ Umar menjadi tokoh yang sangat fenomenal di masa awal Islam. Keputusannya memeluk agama Islam sungguh mengejutkan orang-orang Quraisy yang menentang Islam dan ajarannya tersebar di tanah Mekah. Mohammad Redha, Omar bin Khattab: The Second Caliph. Cet-1. (Beirut: Dar al-Kotob al-Ilmiyah, 1999), hlm. 14. Muhammad Husain Haekal, Umar bin Khattab: Sebuah Telaah Mendalam Tentang Pertumbuhan Islam dan Kedaulatannya Masa Itu. Penerjemah: Ali Audah. Cet-10. (Jakarta: Litera Antar Nusa, 2009), hlm. 9.

${ }_{29}$ Muhammad Husain Haekal, Umar bin Khattab: Sebuah Telaah Mendalam Tentang Pertumbuhan Islam dan Kedaulatannya Masa Itu, hlm. 9. 
Umar bin Khattab, khalifah kedua, adalah seorang yang luar biasa, diakui sebagai salah satu pribadi yang kuat dan bijaksana. Ia memiliki pandangan yang jauh ke depan, baik, dan jujur. Kehidupannya pantas menjadi sebuah pelajaran yang tepat. Ia adalah seorang pribadi menjadi contoh keberanian, kewaspadaan, keadilan, kejujuran, dan kesederhanaan. Ia tidak membedakan dalam melayani siapapun rakyatnya, baik kaya, miskin ataupun terhormat dan rakyat biasa. ${ }^{30}$

\section{Kebijakan Politik Umar}

Sebagai pemimpin yang dikenal tegas dan berani, Umar disegani oleh kawan maupun lawan politiknya. Banyak kebijakan yang lahir pada masa kepemimpinannya, baik yang diterima secara luas maupun yang menuai kontroversi. Namun begitulah Umar, keteguhan hatinya tidak dapat digoyahkan oleh pihak manapun. Hidupnya selalu bebas dari intervensi pihak manapun. ${ }^{31}$

\section{Membebaskan Tawanan Pemberontak}

Tak lama setelah para sahabat terkemuka membaiatnya sebagai bukti kesetiaan dan kesiapan membelanya sebagai pemimpin pemerintahan Islam, Umar mengeluarkan kebijakan politik kontroversial di 100 hari kepemimpinannya. Keberaniannya dalam memutuskan perkara bukan hanya berdasarkan hitung-hitungan politis, namun aspek kemanfaatan bagi pemerintahan Islam yang diembannya yang masih berusia muda.

Kebijakan pertamanya adalah membebaskan tahanan politik Perang Yamamah. ${ }^{32}$ Di masa Abu Bakar, muncul pemberontakan dari kabilah-kabilah Jazirah Arab pasca wafatnya Nabi Muhammad SAW. Mereka mendeklarasikan untuk keluar dari barisan Islam yang dipimpin Khalifah Abu Bakar. Salah satu bentuk penolakan mereka untuk memboikot

${ }^{30}$ Mohammad Redha, Al-Farouk Omar Ibn al- Khattab The Second Caliph. Cet-1. (Beirut: Dar al-Kotob al-Islamiyah, 1999), hlm. 7.

${ }^{31}$ Abd al-Jabbar, Khulashah Nur al-Yaqinfi Siyarati Sayyid al-Mursalin, Juz 3, (Surabaya: Maktabah Muhammad bin Ahmad Nabhan wa Auladih, t.t.), hlm. 89.

32 Perang Yamamah terjadi pada tahun 11 H/632 M. Pemberontak dipimpin oleh tokoh-tokoh yang mengaku sebagai nabi dan mendeklarasikan keluar dari barisan Islam pimpinan Abu Bakar dan enggan membayar zakat. Para pemimpinnya adalah Musailamah alKazzab, Sajah Tamimiyah, dan Tulaihah bin Khuwailid. A. Latif Osman, Ringkasan Sejarah Islam, Cet-30. (Jakarta: Widjaya, 2000), hlm. 39. 
pemerintahan Abu Bakar adalah keengganan mereka membayar zakat sebagaimana yang mereka telah lakukan di masa nabi. Maka dengan hal ini, Abu Bakar memerangi mereka. ${ }^{33}$

Umar memiliki alasan-alasan yang kuat akan keputusannya membebaskan para tawanan. Secara politis ia membutuhkan dukungan seluruh kabilah di Jazirah Arab, karena saat itu eksistensi Islam terancam oleh Byzantium ${ }^{34}$ dan Persia. ${ }^{35}$ Kedua, demi menjaga persatuan dan kemaslahatan umat.

\section{Ekspansi Islam}

Umar melanjutkan ekspansi yang telah dimulai oleh Nabi Muhammad SAW dan Abu Bakar. Wilayah-wilayah yang menjadi target sasaran adalah Roma Timur (Byziantium) yang meliputi bagian Barat Asia dan pesisir utara Afrika, kemudian wilayah Imperium Persia sampai perbatasan Asia Tengah. Wilayah-wilayah tersebut adalah ancaman yang berpotensi menganggu eksistensi pemerintahan Islam yang berpusat di Jazirah Arab, yakni Madinah sebagai ibukota negara. ${ }^{36}$

${ }_{33}$ Muhammad Husain Haekal, Umar bin Khattab: Sebuah Telaah Mendalam Tentang Pertumbuhan Islam dan Kedaulatannya Masa Itu. Penerjemah: Ali Audah. Cet-10. (Jakarta: Litera Antar Nusa, 2009), hlm. 84.

${ }^{34}$ Byzantium adalah sebuah kerajaan besar yang muncul tahun 527-1453 M. Sebelum Islam lahir di Mekah, kerajaan ini sudah lahir terlebih dahulu. Kemunculan Islam merupakan ancaman bagi eksistensi mereka. Karl Krumbacher, The History of Byzantine Literature: from Justitian to the end of the Eastern Roman Empire (527-1453). (University of Notre Dame, 2001), hlm. 2 . Diunduh

dari http://www.google.co.id/url?sa=t\&rct=j\&q=the\%20history\%20of\%20byzantium\%20and\%20persi a.pdf\&source=web\&cd $=5 \& c a d=$ rja\&ved $=0 \mathrm{CDsQFjAE \& url=http} \% 3 \mathrm{~A} \% 2 \mathrm{~F} \% 2 \mathrm{Fwww}$.library.nd.ed u\%2Fbyzantine_studies\%2Fdocuments\%2Fkrumbacher.pdf\&ei=Q5-

AUPLcFsSViAfkvIDQCg\&usg=AFQjCNEU5rCCq5-aHdtWkXPiV1MFvVPCUQ .

Lihat juga Beate Dignas and Engelbert Winter, Rome and Persia in Late Antiquity: Neoghbours and Rivals, Cet-1, (New York: Cambridge University Press, 2007), hlm. 13.

35 Kerajaan Persia adalah kerajaan yang ada di wilayah Iran dan sekitarnya. Dipimpin oleh Raja Kisra dan keturunannya. Beate Dignas and Engelbert Winter, Rome and Persia in Late Antiquity: Neoghbours and Rivals, Cet-1, (New York: Cambridge University Press, 2007), hlm. 13.

36 Dalam sejarah tercatat bahwa ekspansi yang dilakukan oleh Islam bukanlah imperalisme seperti yang dilakukan Barat. Islam bertujuan menjaga eksistensinya dari ancaman-ancaman pihak luar terutama Byzantium dan Persia yang selalu menganggu dan mengancam Islam. Paryadi, Umar bin Khattab: Founder and Administrator of Muslim. Ittihad Jurnal Kopertais Wilayah XI Kalimantan, Volume 6 No. 10 Oktober 2008, hlm. 54. 


\section{Kebijakan Ekonomi}

Umar memiliki pemikiran akan ekonomi yang luas. Kecerdasan dan keberaniannya melahirkan banyak kebijakan ekonomi yang berbeda dari apa yang telah dilakukan oleh pendahulunya Abu Bakar. Berikut pemikiran Abu Bakar:

a. Negara mengambil kekayaan umum dengan benar dan tidak mengambil harta kharaj dan $f a i^{\prime}{ }^{37}$ yang mekanismenya untuk rakyat.

b. Negara memberikan subsidi terhadap kebutuhan rakyat. Hal ini dilakukan terutama di saat terjadi musim kekeringan yang menyulitkan rakyat.

c. Pemasukan negara berasal dari kharaj dan ghanimah. ${ }^{38}$ Umar mewajibkan rakyatnya membayar kharaj. Selain itu, sebagaimana sudah dimulai zaman nabi, negara mendapatkan pemasukan sebagai kas negara berasal dari zakat, 1/5 harta rampasan perang, jizyah, ${ }^{39}$ dan bea cukai.

d. Umar menjadikan Bait al-Mal sebagai lembaga keuangan negara. Dari kas inilah negara menggaji pasukan, pejabat pemerintah, dan memberikan subsidi untuk rakyat. Lembaga ini dipimpin oleh Menteri Keuangan yang berada di bawah pengawasan khalifah. ${ }^{40}$

\section{Politik Hukum}

Sebelum dan ketika menjadi khalifah, Umar terkenal dengan sahabat yang paling sering melakukan terobosan hukum terhadap perkara-perkara yang belum diatur dalam sumber hukum Islam, yakni Al-Quran dan AlSunnah. Berikut beberapa kebijakannya dalam bidang hukum:

37 Kharaj adalah pajak tanah yang dikenakan bagi tuan tanah yang menguasai wilayah-wilayah tertentu. Sedangkan fai adalah harta rampasan hasil perang yang didapatkan tanpa terjadi pertempuran. Khalid Ramadan Hasan, Mu'jam Ushul al-Figh, (Kairo: al-Raudhah, t.t.), hlm. 36.

${ }^{38}$ Ghanimah adalah harta rampasan yang didapatkan dari pertempuran melawan musuh. Khalid Ramadan Hasan, Mu'jam Ushul al-Figh, (Kairo: al-Raudhah, t.t.), hlm. 30.

${ }^{39}$ Jizyah adalah dana yang dipungut dari orang-orang nonmuslim sebagai jaminan keamanan mereka menjadi warga negara Islam. Ini untuk membedakan dengan muslim yang dikenakan kewajiban zakat. Khalid Ramadan Hasan, Mu'jam Ushul al-Fiqh, (Kairo: al-Raudhah, t.t.), hlm. 32 .

${ }^{40}$ Mohammad Redha, Al-Farouk Omar Ibn al- Khattab The Second Caliph, hlm. 38. 
a. Umar tidak menghukum seorang pencuri dengan hukuman maksimal yakni potong tangan disebabkan perbuatan mencuri yang dilakukan adalah karena terdesak akan kesulitan ekonomi. Akhirnya si pencuri hanya dihukum $t a^{\prime} z i r$ yang lebih ringan. Keputusan Umar ini menjadi yurisprudensi bagi para ahli hukum Islam kemudian. ${ }^{41}$

b. Bagian zakat kepada muallaf tidak lagi diberikan kepada mereka. Hal ini dilakukan dengan alasan perubahan kondisi pada diri mereka dan Islam yang sudah kuat. ${ }^{42}$

c. Umar merumuskan kodifikasi kitab suci Al-Quran menjadi sebuah mushaf yang kemudian disebarkan. Ini merupakan terobosan kebijakan politik hukum tersebar yang dikenang sepanjang masa oleh umat muslim. ${ }^{43}$

\section{Politik Hukum Responsif}

Kebijakan politik hukum yang diambil Umar selama menjadi khalifah adalah kebijakan politik hukum responsif. Dalam kebijakan hukumnya, Umar tidak hanya berpatokan secara kaku terhadap aturan hukum yang sudah ada. Ia berani menerobos aturan hukum yang ada dalam kaidah-kaidah yang sudah tertulis. Contoh paling menarik adalah tentang peniadaan hukuman potong tangan bagi pencuri dengan alasan kondisi negara yang sedang paceklik, di mana kondisi ekonomi sedang tidak stabil. Secara psikologipun, si pencuri melakukan kejahatan pencurian bukan untuk kesenangan, tetapi untuk mengisi perutnya dan keluarganya yang kelaparan. ${ }^{44}$

\section{Kesimpulan}

Islam adalah agama dan negara. Kesempurnaannya mengatur segala aspek kehidupan manusia antara lain ibadah, etika atau akhlak, hubungan

${ }^{41}$ Mohammad Redha, Al-Farouk Omar Ibn al- Khattab The Second Caliph, hlm. 79.

${ }^{42}$ Muhammad Husain Haekal, Umar bin Khattab: Sebuah Telaah Mendalam Tentang Pertumbuhan Islam dan Kedaulatannya Masa Itu, hlm. 203.

${ }^{43}$ A. Latif Osman, Ringkasan Sejarah Islam, Cet-30. (Jakarta: Widjaya, 2000), hlm. 78.

${ }_{44}$ Bandingkan konsep politik hukum responsif dalam Phillipe Nonet dan Philip Selzick, Law and Society in Transition: Toward Responsive Law. Kumpulan tulisan dalam Constitutionalism and Democracy. Buku I Politik Hukum yang dikumpulkan oleh Satya Arinanto, Program Pascasarjana Fakultas Hukum Universitas Indonesia. Edisi 1, 2001, hlm. 233. 
manusia dan masyarakat. Maka sangat tidak berlebihan dalam sejarah disebutkan bahwa Islam di Madinah bukan hanya membangun sebuah agama, namun juga peradaban sebuah negara dan pemerintahan yang berdaulat.

Islam tidak mengenal sistem demokrasi dalam ajarannya. Meskipun demikian Islam memiliki konsep tersendiri tentang sistem negara dan pemerintahan. Nabi dan para sahabat telah membangun konsep sebuah sistem yang bersumber dari nilai-nilai ajaran Islam dan pengalamanpengalaman empiris. Ketika demokrasi memiliki sistem pemilihan oleh rakyat, maka Islam memiliki model antara lain lembaga ahl al-aqdi wa al-hilli. Mereka adalah terdiri dari wakil-wakil yang menjadi representasi rakyat.

Masa pemerintahan Umar bin Khattab dapat menjadi sebuah contoh kebijakan politik hukum responsif dalam sejarah Islam. Berbagai terobosan kebijakan yang dilakukannya menghasilkan catatan-catatan penting bagi para ahli hukum Islam di masa kemudian.

\section{Pustaka Acuan}

Al-Jabbar, Umar Abd. Khulashah Nur al-Yaqinfi Siyarati Sayyid al-Mursalin. Juz 1. Surabaya: Maktabah Muhammad bin Ahmad Nabhan wa Auladih, t.t. Khulashah Nur al-Yaqinfi Siyarati Sayyid al-Mursalin. Juz 2. Surabaya: Maktabah Muhammad bin Ahmad Nabhan wa Auladih, t.t.

Khulashah Nur al-Yaqinfi Siyarati Sayyid al-Mursalin. Juz

3. Surabaya: Maktabah Muhammad bin Ahmad Nabhan wa Auladih, t.t.

Al-Mawardi, Abu al-Husain Ali bin Muhammad. Al-Ahkam al-Sulthaniyah wa al-Wilayat al-Diniyah. Cet-3. Beirut: Dar al-Kotob al-Islamiyah, 2006.

Al-Mubarakfuri, Syaikh Syaifurrahman. Sirah Nabawiyah. Penerjemah: Kathur Suhardi. Cet-1. Jakarta: Pustaka Al-Kautsar, 1997.

Azhary, Muhammad Tahir. Negara Hukum: Suatu Studi Tentang Prinsipprinsipnya Dilihat dari Segi Hukum Islam, Implementasinya pada Periode 
Madinah dan Masa Kini. Edisi Kedua. Cet-2. Jakarta: Kencana Prenada Media, 2004.

Dignas, Beate and Engelbert Winter. Rome and Persia in Late Antiquity: Neoghbours and Rivals. Cet-1. New York: Cambridge University Press, 2007.

Haekal, Muhammad Husain. Umar bin Khattab: Sebuah Telaah Mendalam Tentang Pertumbuhan Islam dan Kedaulatannya Masa Itu. Penerjemah: Ali Audah. Cet-10. Jakarta: Litera Antar Nusa, 2009.

Hasan, Khalid Ramadan. Mu'jam Ushul al-Figh. Kairo: al-Raudhah, t.t.

Huwaydi, Fahmi. Demokrasi, Oposisi, dan Masyarakat Madani. Penerjemah: Muhammad Ghaffar. Bandung: Mizan, 1996.

Krumbacher, Karl. The History of Byzantine Literature: from Justitian to the end of the Eastern Roman Empire (527-1453). University of Notre Dame, 2001.

Lijphart, Arend. Democracies: Patterns of Majoritarian and Consensus Government in Twenty-One Countries. Dalam Politik Hukum 1 yang dikumpulkan oleh Satya Arinanto, Program Pascasarjana Fakultas Hukum Universitas Indonesia. Edisi 1, 2001.

Muslim, Abu al-Husain bin al-Hajjaj. Shahih Muslim. Juz 4, cet-1. Beirut: Dar al-Hadis, 1997.

Nonet, Phillipe dan Philip Selzick. Law and Society in Transition: Toward Responsive Law. Kumpulan tulisan dalam Constitutionalism and Democracy. Buku I Politik Hukum yang dikumpulkan oleh Satya Arinanto, Program Pascasarjana Fakultas Hukum Universitas Indonesia. Edisi 1, 2001.

Osman, A. Latif. Ringkasan Sejarah Islam. Cet-30. Jakarta: Widjaya, 2000.

Oxford Advance Learner Dictionary. $5^{\text {th }}$ edition. New York: Oxford University Press. 2008.

Paryadi, Umar bin Khattab: Founder and Administrator of Muslim. Ittihad Jurnal Kopertais Wilayah XI Kalimantan, Volume 6 No. 10 Oktober 2008.

Przeworski, Adam. Democracy as a Contingent Outcome of Conflicts. Kumpulan tulisan dalam Constitutionalism and Democracy. Buku I Politik Hukum yang dikumpulkan oleh Satya Arinanto, Program Pascasarjana Fakultas Hukum Universitas Indonesia. Edisi 1, 2001. 
Rasjidi, M. Koreksi Terhadap Dr. Harun Nasution tentang Islam Ditinjau dari Berbagai Aspeknya. Jakarta: Bulan Bintang, 1977.

Redha, Mohammad. Al-Farouk Omar Ibn al- Khattab The Second Caliph. Cet-1. Beirut: Dar al-Kotob al-Islamiyah, 1999.

Said, Imam Ghazali. Antara Piagam Madinah dan Konstitusi Indonesia: Antara Idealisasi Syariat Islam dan Lokalitas Sosio-Kultural Masyarakat Indonesia. Kumpulan tulisan dalam buku Formalisasi Syariat Islam di Indonesia: Sebuah Pergulatan Yang Tak Pernah Putus. Cet-5. Jakarta: Renaisan, 2005.

W.J.S. Poerwadarminta, Kamus Umum Bahasa Indonesia, bagian pertama, cet-4. Jakarta: Balai Pustaka, 1966.

Zuhaili, Wahbah. Al-Wajiz fi Ushul al-Figh. Beirut: Dar al-Fikr al-Mu'ashir, 1999. 